\title{
Emotional factor in the etiology and pathogeny of cancer
}

\author{
José R Ponce ${ }^{1 *}$ and Joel Martínez ${ }^{2}$ \\ ${ }^{1}$ University of Humanistic Psychoanalysis, Brazil \\ ${ }^{2}$ Second Degree in Oncology, FEMA, USA
}

\begin{abstract}
The results of a literature review about the relationship of emotional stress, in its different manifestations, with cancer disease are exposed. Since Galen (129-216 $\mathrm{BC}$ ), in his book De Tumoribus noted that "melancholic" women were more prone to cancer than others, has been wondering about what is true in those suspicions. Especially that the clinical practice of many specialists points towards a close relationship between this disease and stress-derived states, such as chronic depression for example. The cancer is chronic and still unknown in its cause. It consists in the atrophied and progressive growth of the cells in any part of the body, to create a tumor, or to circulate through body fluids such as blood or lymph. Such growth can metastasize to distant sites, and could lead to death. Everything indicates up to now that its etiology is really multifactorial, where the toxic-environmental and the genetic-hereditary factor can be pointed out. However, it has been demonstrated how socio-environmental events imprint genetic mutation, and are coadjutant to the neoplastic tissue, being found within these factors to emotional stress. This state is related to cancer in several ways: One, causing genetic mutation, promoting growth of neoplastic tissue. In second place, reduces the defensive capacity of the immune system to against cancer. Third, through depression modifies physiological functions that favor the disease.
\end{abstract}

\section{Introduction}

A mini-review is presented on the bibliography related to the emotional factor in the cancer patient, in its etiology, pathogenesis and treatment. The proposed objective is to carry out a preliminary exploration on the mentioned factors in order to carry out an experimental investigation with a significantly greater sample.

\section{Discussion}

Since Galen (129-216 BC), in his book De Tumoribus noted that "melancholic" women were more prone to cancer than others [1,2], there have been generated suspicions of the participation of the emotional in the origin of that disease. Especially that clinical practice points to a presence of suffering that is not always is clear if it is cause or consequence.

Cooper [3], in his book Stress and Cancer, says that in 1601 cancer was defined as a ...swelling or sore from melancholy blood, around which the veins appear a black or dark color, extending as the claws of a crab. Walshe, in his book The Nature and Treatment of Cancer, published in 1846, attributes this disease to mental misery, loss, and changes in mood.

Cancer is a chronic disease of multifactorial etiology [4]. It consists of atrophied growth of cells anywhere in the body, to create a tumor, or circulate through body fluids such as blood or lymph. This growth can metastasize to distant sites, and could lead to death [5].

Cancer, and its effect on the patient and his family, is a global problem [6]. According to 2009 reports, in the United States alone, this disease affects approximately twelve million people, covering an estimated $7.2 \%$ in the population over 18 years of age [7].

An approach to the relationship between cancer and emotional stress, on the one hand, contemplates the etiology of the disease, and on the other, the aggravating effect of stress on the disease and the patient's well-being.

Regarding the aggravating effect of stress, emotional imbalance occurs with intensity since the news of having contracted the disease is received [8], resulting in excessive emotional tension, anxiety, fear, hostility, fatigue, confusion. These effects are aggravated by additional stressors such as physical limitations, invasive treatments, and vegetative disorders [9]. In summary, cancer is a source of sustained distress $[10,11]$.

A crucial derivation of stress in cancer patients is depression, the affective disorder most associated with the disease, since the possibility of death causes such a psychic disorder, with the consequent loss of hope and optimism.

Hope has been defined as waiting for a solution to happen [12], fueled by optimism [13]. Its loss in the cancer patient is greater as there is a pessimistic attitude [14], increasing the risk of recurrence and death [15].

Sheppard, et al. [16] conducted a pilot study to determine the effect of the fatalistic attitude of African-American patients with breast cancer. The sample had an average age of 21 years, without metastasis or recurrence. They found that the idea of death in these patients exerted severe damage in mood, and aggravated the symptomatology. Patients with fewer psychological resources to cope with the disease easily suffer

${ }^{\star}$ Correspondence to: José R Ponce, Doctor in Psychoanalysis, Ms. in Health Psychology, University of Humanistic Psychoanalysis, Brazil, Tel: 7863021275; E-mail: joseramon333@hotmail.com

Key words: cancer, stress, immunology, depression

Received: May 23, 2018; Accepted: June 05, 2018; Published: June 08, 2018 
from hopelessness, which is an important predictor of anxiety and depression $[17,18]$.

Optimism and hope are a guarantee to accept new treatments $[19,20]$. In addition, they can be a barrier to severe depression, based on the mechanism of self-efficacy for the management of the disease [21]. In short, they facilitate the concentration of attention to achieve effect with Complementary techniques [22,23]. Matthews \& Cook report a study showing the favorable effect of hope [24]. Ninety-three women with breast cancer were taken, between phases I and IV, and between 39 and 79 years of age. In this sample it was observed that this attitude correlated with low level of depression

Schrank, et al. [25] analyze the concept of hope, and consider that this has been studied in the literature, firstly, in association with emotion, secondly, with cognition, and thirdly associated with both functions. They also concluded that hope allows for better social functioning, reducing vulnerability to stress, better coping skills, and increasing the effectiveness of psychotherapy.

Given the stressful conditions of the patient with cancer, social support is a crucial factor in achieving their well-being; they require emotional support from family, nurses, doctors, and others around them.

Social support is an external regulator of the stress response, and provides a feeling of protection in difficult times. It also allows greater possibility of communication, and therefore promotes catharsis. To this is added that it allows orientation, distraction, diversification of interests, and satisfaction of gregarious need. Social support systems are stratified as a couple, family, friends, social institutions, health centers, and religious and social groups.

The relationship between social support and cancer is manifested through the psychological and endocrine-immunological pathways. Psychologically, social support favors adherence to treatment and better coping with depression. The physiological pathways are related to the increase of oxytocin, as a result of stress reduction, which is added to the normalization of cortisol and catecholamine. The latter implies the increase of defensive capacity of NK cells, and better functioning of cytokines [26].

With respect to the hypothetical participation of stress in the etiology of cancer, the studies of Caroline Bedell Thomas, this found a high correlation index between loneliness and said disease, stood out. This author carried out a longitudinal study with a sample of 1337 medical students between 1948 and 1964. The results of this study indicate that this disease is frequently manifested in those with diminished capacity for expression and depressive tendencies.

These findings involved new studies of experimental models in animals, mainly mice. It was observed that electrical shock, intense noise or isolation, caused growth of cancerous tissue by decreasing immunity capacity [27]. These studies contributed to Psychoneuroimmunology.

The most distant premises of this scientific branch are found in the studies of Tohru Ishigami, who observed a close relationship between the immune system and emotional state in tuberculosis patients. Ishigami, from Walter Cannon's studies on adrenal secretion and physical arousal, carried out clinical investigations, with humans and animals, around the emotion and said lung disease [28-31].

The hypothetical role of stress in the etiology of cancer is shown more clearly through the modification that this state exerts on the genetic-hereditary factor. It has been shown as socio-environmental events print a genetic mutation that facilitates the growth of the neoplasia; within these factors is emotional stress [32,33].

Not only is there the probability that stress intervenes in the etiopathogenesis of cancer through genetic mutation, but also by processes of the endocrine-immune system. In a state of stress, abnormal endocrine secretion occurs, especially catecholamine, ACTH, and cortisol, which impair the immune defense capacity, facilitating neoplastic growth [34].

This hormonal cascade impairs T and B lymphocytes, CD4 cells, and NK cells. The damage to the defensive capacity of the cytosines Interlukin 1, Interleukin 6, some interferons, and the Tumor Necrosis Factor is also added; all components in the defense against cancer [35].

A prominent place in the study of the relationship between stress and cancer is cancer in children. The psychological impact is more aggressive due to their inability to understand the situation sufficiently, and the difficulty in handling symptoms. More complex is the family situation, especially because of the emotional impact given the patient's situation or management, and their probable loss of life [36].

Added to this is the effect on the family of the suffering caused in the child by chemotherapy, radiation, surgery, bone marrow transplantation, or any other physical intervention; given the grievance of hospitalization [37]. There is also fatigue, anxiety, depression [38], and post-traumatic stress [39].

Finally, regardless of any hypothesis, puzzling cases of spontaneous remission of cancerous tissue are reported, considering that religious faith, intensely maintained, and with absolute conviction in the visualization of an omnipotent superior power, exerts an effect on the immune system that causes the disease to subside [40].

\section{Conclusions}

The data obtained through this review suggest the need to study in greater magnitude the relationship of emotional stress with cancer. The review of the literature on the subject leads to the suspicion that this state intervenes in some way in the etiopathogenesis of this disease, but nevertheless there are still many questions and different edges in that relationship.

\section{References}

1. Fife A, Beasley PJ, Fertig DL (1996) Psychoneuroimmunology and cancer: Historical perspectives and current research. Adv Neuroimmunol 6: 179-190.

2. Valiente M (2006) El uso de la visualización en el tratamiento psicológico de enfermos de cáncer. Psico-oncologia 3: 19-34.

3. Cooper CL (1986) Estrés y Cáncer. Ediciones Díaz de Santos SA: Madrid.

4. Arbizu JP (2010) Factores psicológicos que intervienen en el desarrollo del cáncer y la respuesta al tratamiento. Servicio de Oncología del Hospital de Navarra, Suplemento: Pamplona, España.

5. Marks DF, Murray M, Evans B, Estacio EV (2011) Health Psychology: Theory, Research, and Practice, $\left(3^{\text {rd }}\right.$ Edn). London.

6. Groot MT, Baltussen R, Uyl-de Groot CA, Anderson BO, Hortobágyi GN (2006) Costs and Health Effects of Breast Cancer Interventions in Epidemiologically Different Regions of Africa, North America, and Asia. Breast J 12: 81-90.

7. Underwood M, Townsend JS, Stewart Sh, Buchannan N, Ekwueme DU, et al. (2012) Surveillance of Demographic Characteristics and Health Behaviors among Adult Cancer Survivors - Behavioral Risk Factor Surveillance System, United States, 2009. MMWR 20: 61.

8. Campos RC, Besser A, Ferreira R, Blatt SJ (2012) Self-Criticism, Neediness, and Distress among Women Undergoing Treatment for Breast Cancer: A Preliminary Test of the Moderating Role of Adjustment to Illness. Int J Stress Manag 19: 151-174. 
9. Gutman DA, Nemeroff CB (2011) Stress and depression. In R. J. Contrada \& A. Baum (Eds.). The handbook of stress science: Biology, psychology, and health, 345-357. New York, NY: Springer Publishing Company.

10. Leigh AF, Heather SJ, Williams Ch, Loftus L, Jacobsen PB (2010) Relationship of stress management skill to psychological distress and quality of life in adults with cancer. Psychooncology 19: 102-109.

11. Baum A, Trevino LA, Dougall AL (2011) Stress and the cancers. In R. J. Contrada \& A. Baum (Eds.), The handbook of stress science: Biology, psychology, and health New York, pp 420-421.

12. Folkman S (2010) Stress, coping, and hope. Psychooncology 19: 901-908. [Crossref]

13. Rand KL (2009) Hope and optimism: latent structures and influences on grade expectancy and academic performance. J Pers 77: 231-260. [Crossref]

14. Ariyabuddhiphongs V, Li J (2012) Sacrifice and Optimism among Thai Masseuses: The Mediating Role of Pride. International Perspectives in Psychology: Research, Practice 1: 154-164.

15. Tacón AM (2003) Meditation as a complementary therapy in cancer. Fam Community Health 26: 64-73. [Crossref]

16. Sheppard VB, Davis K, Boisvert M, Jennings Y, Montalvo B (2011) Do Recently Diagnosed Black Breast Cancer Patients Find Questions About Cancer Fatalism Acceptable? A Preliminary Report. J Canc Educ 26: 5-10.

17. Delahaij R, Van Dam K, Gaillard AWK, Soeters J (2011) Predicting Performance Under Acute Stress: The Role of Individual Characteristics. Int J Stress Manag 18: 49-66.

18. Rasmussen HN, Scheier MF, Greenhouse JB (2009) Optimism and physical health: a meta-analytic review. Ann Behav Med 37: 239-256. [crossref]

19. Eliott JA, Olver IN (2009) Hope, life, and death: a qualitative analysis of dying cancer patients' talk about hope. Death Stud 33: 609-638. [crossref]

20. Farnell B, Varela CR (2008) The Second Somatic Revolution. J Theory Soc Behav 38: 0021-8308.

21. Hazlett A, Molden DC, Sackett AM (2011) Hoping for the Best or Preparing for the Worst? Regulatory Focus and Preferences for Optimism and Pessimism in Predicting Personal Outcomes. Social Cognition 29: 74-96.

22. Lee MK, Baek SK, Kim S, Heo DS, Yun YH, et al. (2011) Awareness of incurable cancer status and health-related quality of life among advanced cancer patients: A prospective cohort study. Palliat Med 27: 144-154.

23. American Cancer Society (2012) Complementary and alternative methods for cancer management.
24. Matthews EE, Cook PF (2009) Relationships among optimism, well-being, selftranscendence, coping, and social support in women during treatment for breast cancer. Psychooncology 18: 716-726.

25. Schrank B, Woppmann A, Sibitz I, Lauber Ch (2010) Development and Validation of an Integrative Scale to Assess Hope. Health Expect 14: 417-428.

26. Lunde IG, Anton SL, Bruusgaard JC, Rana ZA, Ellefsen S, et al. (2011) Hypoxia inducible factor 1a links fast-patterned muscle activity and fast muscle phenotype in rats. J Physiol 589: 1443-1454.

27. Ishigami $\mathrm{T}$ (1919) The influence of psychic acts on the progress of pulmonary tuberculosis. Am Rev Tuberc 2: 470-484.

28. Bammer K, Newberry B (1985) El estrés y el cáncer. Barcelona, España: Editorial Herder.

29. Taguchi F (2003) Tohru Ishigami (1) Japan Medical Journal 4118: 41-43.

30. Taguchi F (2003) Tohru Ishigami (2) Japan Medical Journal 4119: 43-46.

31. Hashiramoto A, Katafuchi T (2009) Mental State and Tuberculosis-Tohru Ishigami 1928 Retrieved January 22, 2014 from Mental State and Tuberculosis- Tohru Ishigami 1928.

32. Antoniou AC, Chenevix-TG (2010) Common genetic variants and cancer risk in Mendelian cancer syndromes. Curr Opin Genet Dev 20: 299-307.

33. Den Heijer M, Seynaeve C, Vanheusden K, Duivenvoorden HJ, Bartels CCM, et al (2011) Psychological distress in women at risk for hereditary breast cancer: the role of family communication and perceived social support. Psychooncology 20: 1317-1323.

34. Kendall-Tackett K (Eds) (2010) The psychoneuroimmunology of chronic disease: Exploring the links between inflammation, stress and illness. American Psychological Association. Washington, DC.

35. Hudacek KD (2007) A Review of the Effects of Hypnosis on the Immune System in Jay, S.M., Elliot, Ch. \& Varni, J.W. (1986) Acute and Chronic Pain in Adults and Children with Cancer. J Consult Clin Psychol 54: 601-607.

36. Contrada RJ, Baum A (Eds.) (2011) The handbook of stress science: Biology, psychology, and health. New York, NY: Springer Publishing Company.

37. Long KA, Marsland AL (2011) Family adjustment to childhood cancer: a systematic review. Clin Child Fam Psychol Rev 14: 57-88. [Crossref]

38. Merrill RM, Brown RJ, Alder S, Baker RK, Byrd AD, et al. (2007) Psychological disorders among children and the parents of children undergoing cancer workup. $J$ Psychosoc Oncol 25: 1-18.

39. Phipps S, Jurbergs N, Long A (2009) Symptoms of post-traumatic stress in children with cancer: does personality trump health status? Psychooncology 18: 992-1002. [Crossref]

40. Westcott R (2002) Can miracles happen? British Medical Journal 325: 7363.

Copyright: ( 2018 Ponce JR. This is an open-access article distributed under the terms of the Creative Commons Attribution License, which permits unrestricted use, distribution, and reproduction in any medium, provided the original author and source are credited. 